kiem, w praktyce radzi się, by lectio divina trwała co najmniej kwadrans, jeżeli ma być rzeczywiście spokojną refleks ą i modlitwą ${ }^{21}$.

Kończąc tymi praktycznymi uwagami na temat wprowadzenia i miejsca lectio divina w formacji seminaryjnej, wypada życzyć, aby ożywienie tej praktyki przyczyniło się do jak największego ukochania prżez alumnów Słowa Bożego, które potem głoszone z mocą w posłudze i życiu kapłańskim stawałoby się życiem całego ludu Bożego.

Przemyśl

KS. STANISEAW HAREZZGA

21 Zob. G. Martin, dz. cyt., 18-20.

\title{
Bogusiaw Dąbrowski
}

\section{PIECZĘĆ KRÓLEWSKIEGO SLUGI}

Od kilkunastu lat realizowany jest w Jordanii program majacy na celu powierzchniowe przebadanie terenów wokól Madaby (znanej z mozaikowej mapy Pale:tyny z VI w. n.e.). Realizacji tego największego archeologicznego przedsięwzięcia w Jordanii podjęli się uczeni z Andrews University w Stanach Zjednoczonych. W ramach projektu prowadzi się także wykopaliska na szerszą skalę $\mathrm{m}$. in. na Tell Hesban (biblijny Heszbon), gdzie odkryto sadzawkę być może opiewana przez jerozolimskiego poetę $\mathrm{w}$ Pnp 7, 5. Po zakończeniu prac na Tell Hesban, w 1984 podjęto wykopaliska na Tell el-Umeiri. Jest to rozległy tell w Jordanii, dotychezas nie badany przez archeologów.

Wzgórze leży około $15 \mathrm{~km}$ na południe od Ammanu, czyli przy południowej granicy biblijnego królestwa Ammonitów. Starożytna nazwa tego miejsca nie jest znana, lecz niektórzy badacze przypuszczają, że chodzi o Abel-Keramim (Sdz 11,33).

Najważniejszym znaleziskiem pierwszejo sezonu (lato 1984), a jak póżniej podawano - jednym z najważniejszych znalezisk archeologicznych ostatnich kilku lat, był odcisk pieczęci należącej do sługi ammonickiego króla Baalisa wspomnianego w Jr 40, 14.

Nieczęsto się zdarza potwierdzenie historyczności jakiejś postaci biblijnej, jest to zawsze znaczącym wydarzeniem poruszającym nie tylko grono uczonych, ale i opinię publiczną.

\section{GRUDKA WYSUSZONEJ ZIEMI}

$\mathrm{Na}$ tellu trwała właśnie normalna, żmudna praca, gdy jeden z pracowników, przesiewając ziemię ze swojego sektora, spostrzegł mała wysuszoną grudkę stożkowatego kształtu. Na szczęście zainteresował 
się nią i stwierdził, że dziwny przedmiot zrobiony jest $z$ wypalonej gliny. Obiekt przekazał kierownictwu ekspedycji. Po wstępnym oczyszczeniu zauważono, że na płackiej stronie znajduje się napis i rysunek.

Znalezienie przedmiotów pokrytych pismem zawsze wzbudza poruszenie. Jednakże napisy te przeważnie zawierają wyszczególnienie imion lub towarów, bardzo rzadko natomiast rzucają światło na historię i religię, a jeszcze rzadziej mają odniesienie do biblijnych sprawozdan.

Prof. Larry G. Herr, jeden z szefów ekspedycji, zidentyfikował wstępnie przedmiot jako odcisk pieczęci $\mathrm{z}$ napisem ammonickim. Kształt liter wskazywał na ok. 600 r. przed Chr. ( \pm 25 lat). Każdy naród zamieszkujący obszar Palestyny, a więc Ammonici, Moabici, Edomici, Filistyni, Hebrajczycy, Aramejczycy i Fenicjanie stosowali ten sam kanaanejski alfabet, lecz używali trochę innych form liter. Badając styl pisma można dokładnie określić, w jakim kręgu kulturowym dany zabytek został wykonany. Jest to pomocne zwłaszcza przy opracowywaniu zabytków o nieznanym pochodzeniu, bez tzw. kontekstu archeologicznego. Styl pisma zmieniał się także z czasem w obrębie jednego narodu. Prześledzenie tego rozwoju daje możliwość do bardziej lub mniej dokładnego datowania.

\section{STAROŻYTNE PIECZĘCI}

Pieczęci odgrywały $w$ starożytności dużą rolę. Były czymś w rodzaju dowodów osobistych. Historia zapisana w Księdze Rodzaju 38, 18, chociaż kilkaset lat starsza od czasów, którymi się zajmujemy, ilustruje nierozłączność człowieka i pieczęci. Były nanizywane na sznurek i zawieszane na szyi lub przegubie dłoni. Posiadały także formę sygnetu. Większość posiadaczy pieczęci stanowili zapewne bogaci właściciele ziemscy, kupcy i urzędnicy królewscy. Używano ich do zatwierdzania umów i podpisywania kontraktów, do potwierdzania własności różnych przedmiotów. Pieczęci z czasów państwa izraelskiego zawierały zazwyczaj imię właściciela, a czasami jego tytuł lub stanowisko.

Obiekt z Tell el-Umeiri, w którym została odciśnięta pieczęć, posiadał kształt stożka. Służył prawdopodobnie jako zatyczka do małego pojemnika na pachnące olejki. Stempel identyfikował właściciela lub byl gwarantem jakości tego, co w środku było zawarte.

\section{ODCZYTANIE NAPISU}

Ođcisk pieczęści podzielony jest na trzy pasy: napis znajduje się w górnym i dolnym pasie, a wizerunek lecacego skarabeusza w środkowym. 
Niewielkie rozmiary zabytku (wielkość monety 5-złotowej) i niewyraźny partiami tekst zmusiły do skorzystania z pomocy mikroskopu elektronowego małej mocy.

Inskrypcja rozpoczyna się $\mathrm{w}$ górnym pasie $\mathrm{i}$, jak $\mathrm{w}$ hebrajskim, biegnie od prawej do lewej. W górnym pasie brzmi ona: lmlkm' wf. Pierwsza litera $l$, zawsze pojawiająca się na początku tego rodzaju tekstów, oznacza przynależność. Tłumaczenie brzmiałoby więc „należące do Milkomura".

Imię Milkomur znaczy: bóg „Milkom jest ogniem”. Podobne znaczenie ma biblijne imię Uriasz (2 Sm. 11): „Jahwe jest ogniem".

Narodowym bogiem Ammonitów był Milkom (1 Krl. 11. 5). Jednak spośród stu ammonickich imion znanych ze źródeł biblijnych i pozabiblijnych żadne nie zawierało imienia boga Milkoma. Fakt ten dziwił uczonych. Fieczęć $z$ Tell el-Umeiri jest więc pierwszym przykładem teoforycznego imienia zawierającego w sobie imię narodowego boga Ammonitów.

\section{KRÓLEWSKIE SYMBOLE}

Większość centralnego pasa zajmuje wizerunek skrzydlatego skarabeusza popychającego dysk słoneczny. Jest to częste przedstawienie na pieczęciach palestyńskich. Motyw tego chrząszcza wywodzi się z Egiptu, gdzie skarabeusz cieszył się wielką popularnością. Wierzono, że skarabeusz pomaga odrodzic się człowiekowi po śmierci, był symbolem wschodzącego słońca - boga Chepri. Wykonywano niezliczone ilości pieczęci i amuletów w formie skarabeusza, które miały chronić od złych mocy.

Typ skarabeusza, jaki znajdujemy na stemplu z Tell el-Umeiri, był w Izraelu i Ammonie symbolem królewskiej władzy. Po bokach znajdują się dwa emblematy $\mathrm{z}$ półksiężycem i dyskiem słonecznym. Te przedstawienia są podobne do innej ammonickiej pieczęci $z$ tego samego okresu, której właściciel nosił tytuł „oficer króla”. Wszystko wskazywałoby na to, że Milkomur był ściśle związany $\mathrm{z}$ dworem królewskim.

Powyżej dwóch emblematów świadczących o wysokiej pozycji Milkomura znajdują się dwie pierwsze litery wyrazu cbd (hebr. ebed) znaczącego ,sługa". Trzecia litera rozpoczyna napis w dolnym pasie. Jest to bardzo ciekawy tytuł pojawiający się na pieczęciach. Spośród 400 pieczęci z napisami z obszaru Palestyny, które przebadał prof. Herr, jedynie 21 zawierało tytuł ,sługa”. Chociaż sam termin, jakbyśmy przypuszczali, nie posiada nic ze szlachetności, to jednak we wszystkich przypadkach, w których się on pojawia, chodzi o sługę króla. W sześciu przypadkach tytuł po prostu brzmi "sługa króla", w pozostałych pojawia się imię władcy (aramejskiego, hebrajskiego, edomickiego, ammonickiego) znanego zazwyczaj z innych źródeł. Gli- 
niany odcisk zostal znaleziony blisko masywnej konstrukcji o grubych, kamiennych murach, nazwanej przez archeologów cytadelą. Chociaż nie wiadomo, w jakiej dziedzinie Milkomur służył królowi, możliwe jest, że był administratorem tej cytadeli.

W Biblii sługa króla, jak wielu przypuszcza, to jeden $z$ najwyższych urzędników, ktoś w rodzaju członka gabinetu rządowego. W Ewangelii Mateusza 18, 23-35 zapisana jest przypowieść Chrystusa mówiąca o królu robiącym obrachunek ze swymi sługami. Jeden $\mathrm{z}$ nich był winny królowi dziesięć tysięcy talentów, czyli bardzo dużo. Nie chodziło więc tu o zwykłego domowego posługacza, ale o osobę wysoko postawioną w myśl koncepcji przedstawionej powyżej.

\section{KRÓL BAALIASZA}

Należało się spodziewać, że w dolnym pasie pojawi się imię ammonickiego władcy. Badacze zastanawiali się, czy będzie to władca nieznany, bowiem historia Ammonu jest jeszcze niekompletna.

W miarę odczytywania wyloniło się imię Baaliasza bclyšc, co znaczy „Baal jest moim ratunkiem”. Baal może oznaczać boga burzy i urodzaju, baal to także wyraz pospolity o znaczeniu "wiadca" lub „,właściciel”, przez co mógł określać każdego boga (Hebrajczycy wystrzegali się tego określenia $\mathrm{w}$ stosunku do Jahwe). Także kobiety zwracały się do swych mężów per baal, gdyż w tamtejszych kulturach małżonek to także właściciel żony.

$\mathrm{Na}$ podstawie stylu pisma stwierdzono, że Baaliasza panował w Ammonie ok. 600 r. przed Chr. Co więc, Księga Jeremiasza wspomina pewnego ammonickiego króla o imieniu Baalis mającego udział w zamordowaniu w 582 Godoliasza, namiestnika babilońskiego w Judzie po ostatecznym zniszczeniu Jerozolimy w $586 \mathrm{r}$. Pasuje to dokładnie do okresu, na który została datowana pieczęć z Tell el-Umeiri. Baalis i Baaliasza byli królami Ammonu i żyli w tym samym okresie. Czy byla to jedna i ta sama osoba?

Zastanawia nieznaczna różnica w pisowni tych imion. Wysuwano przypuszczenie, że pisarz biblijny świadomie zmienil imię ammonickiego króla, w którym idea zbawienia przypięta jest pogańskiemu bogu. Gorliwy jahwista nie mógł tego znieść. Za tą tezą miałby przema"wiac znany powszechnie fakt zmiany imienia boga Ekronu. Baal Zebul („książę Baal”), poświadczony w tekstach ugaryckich, został zmieniony przez pisarzy hebrajskich na ironiczne Baal Zebub (,,pan much") (Król 1, 2).

Ponieważ większość imion w Biblii zachowało swą pierwotną pisownię i znaczenie, odpowiedzi należałoby szukać gdzie indziej. Odwołajmy się do historii opisanej w Sdz 12, 6 gdzie mieszkańcy Transjordanii wymawiali szibbolet, a mieszkańcy Cisjordanii sibbolet. Jest bardzo prawdopodobne, że prorok Jeremiasz zapisał to imię tak jak go wymawiali Hebrajezycy. 
Możemy z pewnością stwierdzić, że król Baalis z Jr 40, 14 i Baaliasza z Tell el-Umeiri to ta sama osoba. Whiosek ten zostal powszechnie zaakceptowany przez uczonych. Wspomnijmy przy okazji, że Księga Jeremiasza jest szczególnie uprzywilejowana pod względem ilości odkrytych pieczęci zawierających imiona osób wymienionych w tej księdze: Berechiasz/Baruch $(26,4)$, Jerahmeel $(36,26)$, Serajasz (51, 59), król Judy Hiskiasz, być może sam prorok Jeremiasz, Jozaniasz $(40,8)$, a ostatnio król Baalis.

Przed odkryciem zastanawiano się nad znaczeniem imienia Baalis nie znajdując konkretnych rozwiązań. Poprzez identyfikację Baalisa z Baaliaszą uzyskujemy jasne wytłumaczenie oparte na zasadach lingwistycznych, a nie na domysłach.

Pieczęć ta jest więc pierwszym pozabiblijnym źródłem odnoszącym się do tego ammonickiego władcy. Poszerza ona tło wydarzeń opisanych przez Jeremiasza i dodaje im kolorytu. Należy się spodziewać, że wykopaliska na Tell el-Umeiri (autor brał udzial w sezonie drugim w 1987), przyniosą dalsze szczegóły dotyczące historii biblijnej.

Kraków

BOGUSEAW DAZBROWSKI

\section{Ks. Stanislaw Urbański}

\section{POJĘCIE ŚWIĘTOŚCI W KAZANIACH HAGIOGRAFICZNYCH O. JÓZEFA MĘCINSKIEGO (1748-1814)}

Dorobek kaznodziejski o. Męcinskiego to 26 tomów kazań wydanych w latach 1782-1809. Większość tych nauk charakteryzuje się prostym stylem, jasnym wykładem i starannym opracowaniem kompozycyjnym. Kaznodzieja podaje $w$ nich także i praktyczne wskazania etyczne. Szczególną wartość, ze względu na przystępnie podane i na przykładach wziętych z życia wyjaśnione zasady wiary i moralności, mają: „Nauki wiejskie do oświecenia prostego ludu” oraz "Nauki wiejskie świątalne".

O. Józef nie budowal swoich kazań w calkowicie oryginalny sposób. Wzorowal się na dorobku kaznodziejskim innych znanych homiletów, zwłaszcza na Concionus opus tripartitum M. Fabera ( $\dagger$ 1653) i Spisilegium catechetico-concionationus J. Clausa († 1775). Fakt ten w niczym jednak nie umniejsza wartości jego nauk. Cieszyły się one bowiem znacznym powodzeniem przez całe dziewiętnaste stulecie, uczono się ich na pamięć, a pojedyncze kazania drukowano jeszcze na początku XX wieku.

Wielkość o. Męcińskiego bardziej widać na tle kaznodziejstwa epoki, w której przyszło mu żyć i działać. Uważany jest nawet za pioniera 